\title{
Hemiazygos continuation of isolated left-sided inferior vena cava into persistent left superior vena cava: rare association of left isomerism
}

\author{
Vineeta Ojha, ${ }^{\oplus}$ Niraj Nirmal Pandey, Priya Jagia
}

Cardiovascular Radiology and Endovascular Interventions, All India Institute of Medical Sciences, New Delhi, Delhi, India

Correspondence to Dr Priya Jagia,

drpjagia@yahoo.com

Accepted 7 April 2019

\section{DESCRIPTION}

A 1-month old child with recurrent cyanotic spells and a transthoracic echocardiogram demonstrating a complex congenital heart disease underwent a CT angiography (CTA) for further evaluation.

Review of CTA images revealed situs ambiguous with left isomerism, with a midline liver and polysplenia on the right side. In addition, multiple ventricular septal defects and pulmonary atresia was noted. An unusual systemic venous drainage pattern was observed, where an isolated left inferior vena cava (IVC) with hemiazygos continuation was seen in the presence of bilateral superior vena cavae (SVC) (figure 1A,B). The dilated hemiazygos vein was seen draining into the persistent left SVC (figure $1 \mathrm{C}, \mathrm{D}$ ), which in turn drained into the right atrium via the coronary sinus. A normal calibre right SVC and the hepatic veins were seen draining into the right atrium (figure 1A).

Congenital interruption of IVC with either azygous or hemiazygos continuation is an extremely rare developmental anomaly, occurring in $0.6 \%-2 \%$ of individuals with congenital heart disease and $0.3 \%$ of individuals without any anomalies. ${ }^{1}$ Hemiazygos continuation of left IVC is even rarer. An isolated leftsided IVC may drain via multiple possible pathways: (1) after receiving the renal veins, the left IVC may cross the midline to the right side and drain into the right atrium (RA); (2) by azygos continuation into the right SVC, ultimately draining into the RA and (3) by hemiazygos continuation, which is the least common. The hemiazygos vein, in turn, can follow any of the following three pathways to finally drain into the RA: (1) hemiazygous vein $\rightarrow$ azygous vein $\rightarrow$ right SVC $\rightarrow$ RA, (2) hemiazygos vein $\rightarrow$ accessory hemiazygous

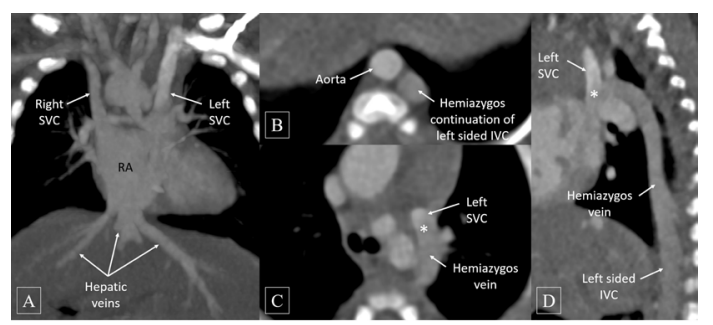

Figure 1 Coronal maximum intensity projection $(A)$ shows all the hepatic veins draining into the RA along with the presence of bilateral SVC. Axial ( $B$ and C) and sagittal (D) maximum intensity projections reveal hemiazygos continuation of the IVC with the hemiazygos vein draining $\left({ }^{*}\right)$ into the persistent left SVC. IVC, inferior vena cava; RA, right atrium; SVC, superior vena cava. vein $\rightarrow$ superior intercostal vein $\rightarrow$ azygos vein $\rightarrow$ right SVC $\rightarrow$ RA or (3) hemiazygos vein $\rightarrow$ persistent left SVC $\rightarrow$ coronary sinus $\rightarrow$ RA. In this case, the last pathway of drainage was observed which is extremely rare.

This extremely uncommon anomaly, in itself, is haemodynamically insignificant; however, awareness and identification of this variant anatomy is important in planning surgical repair in such patients. Challenges in venous cannulation for cardiopulmonary bypass are evident, as the IVC is not in its usual position and the hepatic veins drain directly into the RA, making cannulation of both the SVCs and RA obligatory. Also, in patients planned for a single ventricle repair, a Kawashima procedure (superior cavopulmonary connection) usually suffices in most of the cases instead of a Fontan procedure (total cavopulmonary connection). ${ }^{2}$ This variation may also lead to venous stasis in lower limbs leading to deep vein thrombosis.

\section{Learning points}

- Congenital interruption of inferior vena cava, with either azygos or hemiazygos continuation, is an extremely rare developmental anomaly, occurring in $0.3 \%$ of general population and up to $0.6 \%-2 \%$ of individuals with congenital heart diseases.

- The anomaly, in itself, is haemodynamically insignificant; however, identification of this variant anatomy is important in planning surgical repair as it may pose challenges in venous cannulation for cardiopulmonary bypass and in planning a single ventricle repair.

Contributors All authors participated sufficiently in the conception of the idea, development of the intellectual content, design, writing and final approval of the manuscript.

Funding The authors have not declared a specific grant for this research from any funding agency in the public, commercial or not-for-profit sectors.

Competing interests None declared.

Patient consent for publication Not required.

Provenance and peer review Not commissioned; externally peer reviewed.

\section{REFERENCES}

1 Bass JE, Redwine MD, Kramer LA, et al. Spectrum of congenital anomalies of the inferior vena cava: cross-sectional imaging findings. Radiographics 2000;20:639-52.

2 van der Horst RL, Hastreiter AR. Congenital interruption of the inferior vena cava. Chest 1981;80:638-40. 
Images in...

Copyright 2019 BMJ Publishing Group. All rights reserved. For permission to reuse any of this content visit https://www.bmj.com/company/products-services/rights-and-licensing/permissions/

BMJ Case Report Fellows may re-use this article for personal use and teaching without any further permission.

Become a Fellow of BMJ Case Reports today and you can:

- Submit as many cases as you like

- Enjoy fast sympathetic peer review and rapid publication of accepted articles

Access all the published articles

- Re-use any of the published material for personal use and teaching without further permission

For information on Institutional Fellowships contact consortiasales@bmjgroup.com

Visit casereports.bmj.com for more articles like this and to become a Fellow 